Examining the trade-off between compensation and promptness in eWOM-triggered service recovery: A restorative justice perspective ${ }^{1}$

\author{
Dr. Hongfei Liu ${ }^{2}$ \\ Lecturer of Marketing \\ Essex Business School \\ University of Essex \\ Colchester, CO4 3SQ \\ United Kingdom \\ Email: hongfei.liu@essex.ac.uk
Professor Chanaka Jayawardhena
Professor of Marketing
Faculty of Business, Law and Politics
University of Hull
Hull, HU6 7RX,
United Kingdom
Email: c.jaywardhena@hull.ac.uk \\ Professor Sally Dibb \\ Professor of Marketing and Society \\ Centre for Business in Society \\ Coventry University \\ Coventry, CV1 5FB \\ United Kingdom \\ Email:sally.dibb@coventry.ac.uk \\ Dr. Chatura Ranaweera \\ Associate Professor of Marketing \\ Lazaridis School of Business \\ Wilfrid Laurier University \\ Waterloo, ON, \\ Canada \\ Email: cranaweera@wlu.ca
}

\footnotetext{
${ }^{1}$ Authors would like to thank Dr. Yang Sun for sharing her expertise and experience in restorative justice.

${ }^{2}$ Corresponding author
} 


\title{
Examining the trade-off between compensation and promptness in eWOM-triggered service recovery: A restorative justice perspective
}

\section{Highlights}

- eWOM-triggered service recovery is examined through the novel theoretical lens of restorative justice.

- An experiment is used to examine how hotels' responses to negative online reviews impact upon service recovery.

- The effectiveness of hotels' responses and the optimal recovery strategies depend on the service failure severity.

- Offering compensation and providing a prompt reply work best for less and more severe service failures, respectively.

- Hotels' responsiveness and service recovery satisfaction affect continued use of the eWOM medium by consumers.

\begin{abstract}
Our research examines the effectiveness of monetary compensation and the promptness of response during electronic word-of-mouth (eWOM)-triggered service recovery. Drawing upon restorative justice theories, we explore three main questions: whether the hotel's response to negative online reviews are always beneficial; whether offering compensation or responding promptly is more efficient under different levels of service failure severity; and how the hotel's response influences consumers' future engagement through eWOM media. Experimental results reveal that making minimum online service recovery effort is only effective in fixing consumer attitudes for less severe service failures. Compensation is the optimal solution for less severe failures, while prompt response is optimal for more severe service failures. The hotel's responsiveness to negative reviews and the service recovery outcome positively influence consumers' future eWOM behaviours through the same online medium. Implications for hotels seeking cost-effective management of negative reviews and for online media owners are offered.
\end{abstract}

\section{Key words}

Service recovery; Electronic word-of-mouth (eWOM); Online reviews; Restorative justice; Compensation; Speed of response; Service failure severity; Media engagement 


\section{Introduction}

In today's world, a wide range of electronic word-of-mouth (eWOM) media outlets support the sharing of consumers' reviews about their service experiences. In the hotel industry, online review sites offer an accessible eWOM platform on which service failures can be scrutinised by potential customers and shared with service providers. A recent report suggests that while $97 \%$ of U.S. consumers consult online reviews before making purchase decisions, online reviews have quickly evolved from a "nice-to-have" to an "expected" component of customer experience (PowerReviews, 2018). Moreover, consumers are increasingly generating content and creating a persuasive online environment on review sites (Gonçalyes, Silva, \& Martins, 2018; Sparks, Perkins, \& Buckley, 2013). The significance of these online reviews has encouraged organisations to take strategic action through eWOM engagement (Sparks, So, \& Bradley, 2016; Wu, Shen, Fan, \& Mattila, 2017). However, extant research suggests that the hotel industry's response rate to online reviews, particularly negative reviews, is extremely low. For example, a recent study aggregated the customer reviews and management responses of 3,845 hotels in Texas on Expedia and identified an average response rate of 2.3\% (Proserpion \& Zervas, 2017). General statistics for the US suggest that the management response rate to online reviews is $0.7 \%$. (Kim, Lim, \& Brymer, 2015). Although choosing not to respond to negative online reviews can lead to reputational damage and customer losses, most hospitality providers still adopt a wait-and-see attitude to responding (Chan \& Guillet, 2011; KhooLattimore \& Gibson, 2018).

We address this issue by exploring the extent to which service providers in the hotel sector should respond to negative consumer reviews. Our inquiry is timely for several reasons. First, as Magnini, Ford, Markowski, and Honeycutt (2007) highlight, service failure severity plays an essential role in recovering failed services and re-satisfying customers. This implies that service providers need to take service failure severity into account when adopting recovery strategies (Crisafulli \& Singh, 2017; Zhu, Sivakumar, \& Parasuraman, 2004). While the effect of service failure severity on satisfaction and service recovery is well established, how severity influences the service recovery process and outcomes in the eWOM context is less well understood (Sparks \& Bradley, 2017). Service failures range from severe (e.g. a serious hygiene problem concerning bedding) to less severe (e.g. a slight delay at check-in), all of which could potentially be reflected in the customers' ratings and reviews of the hotel. Despite consumers increasingly using online review sites to complain, the true costs and benefits to providers of responding to these online complaints remain unclear. 
Second, compared with face-to-face complaint handling in the offline environment, hotels have better control in responding to negative reviews (Cantallops \& Salvi, 2014; Chebat \& Slusarczyk, 2005; Wallin Andreassen, 2000). While prior studies claim that responsiveness can create a positive impression among a wide review site audience and increase macro-level sales, its impact on service recovery outcomes remains unclear (Xie, Zhang, \& Zhang, 2014; Ye, Gu, Chen, \& Law, 2008). Our study addresses these gaps by exploring the costs, benefits, and impacts of different service recovery strategies under different scenarios.

Third, previous research has identified various recovery strategies that can assist service providers in coping with customers' complaints. However, most strategies are based on "the more, the better" principle and ignore the cost implications (Homburg \& Fürst, 2005; Liao, 2007; Maxham \& Netemeyer, 2002). Our study tackles this issue by incorporating the costeffectiveness of recovery strategies into the research design.

Finally, while extant research considers the need for hotel service providers to respond to online reviews (Kim et al., 2015), we address a knowledge gap regarding the impact of service recovery outcomes on consumers' future engagement with review sites. In doing so, we heed a recent call for service research and practice to focus on more complex interactions and multi-actor complexity in the digitalised modern recovery process (Van Vaerenbergh, Varga, De Keyser, \& Orsingher, 2018). As such, eWOM media as a new dimension involved in the online service recovery process requires further investigation.

We address our central research objective through a scenario-based online experiment. We examine the effects of service failure severity and recovery effort made through responses to negative online reviews on customers' post-eWOM evaluations of a hotel and behavioural engagement with eWOM media. In the next section, we explain the theoretical foundations and constructs under consideration. We then develop the hypotheses, describe the experimental method, and present the data analysis. Finally, we discuss the implications and provide suggestions for future research.

\section{Theoretical background}

We draw on justice theory to explore cost-effective recovery strategies for hotels. Service recovery refers to "a 'bundle of resources' that an organization can employ in response to a failure" (Smith, Bolton, \& Wagner, 1999, p. 357). The essence of service recovery is to deliver justice and fairness to dissatisfied customers, where justice refers to an individual's evaluative judgement of his or her treatment perceived as fair (Crisafulli \& Singh, 2016; Furby, 
1986). Research has extensively demonstrated the adaptability of justice theory to different contexts, with applications in politics (e.g. Schlosberg, 2013), sociology (e.g. Cook \& Hegtvedt, 1983), criminology (e.g. Kraska, 2006), and marketing and management (e.g. Greenberg, 1987). Use of justice theory in service recovery research is also suitable, with studies widely employing the theory to address hotels' handling of service failures (Chebat \& Slusarczyk, 2005; McColl-Kennedy \& Sparks, 2003).

The underlying premise behind the theory's use is simple: the greater the recovery effort a hotel makes, the greater is the justice delivered to consumers. However, as costs are attached to service recovery efforts (Boshoff \& Allen, 2000; Wirtz \& Mattila, 2004), developing costeffective recovery strategies is a top priority for hotels. In the eWOM context, these costs include financial resources required to compensate consumers and human resource expenditure incurred from the personnel required to deal with the negative reviews. Cost-effectiveness, therefore, refers to a situation in which the hotel satisfactorily achieves service recovery at the optimal cost in terms of financial and human resources.

Restorative justice, which highlights the nature of recovery in the legal process and derives from justice theory, can bring fresh insights to service recovery research (Latimer, Dowden, \& Muise, 2005). For example, Larsen and Lawson (2013) argue that restorative justice is a useful framework for the critical evaluation of consumer rights in service recovery. The nature of restorative justice entails addressing conflict resolution and re-building cohesion between the two parties' opposing interests (Morrison \& Ahmed, 2006; Vaandering, 2013). This process reflects the conflict of interests between hotels and consumers who experience service failure and manifests in the attention hotels devote to customer relationship management in the post-purchase stage (Ha \& Jang, 2009; Kelley \& Davis, 1994). Through the lens of restorative justice, dialogue is mediated between the victims and offenders to reach a mutually satisfying restitution agreement (Umbreit, Coates, \& Vos, 2004).

During mediation, victims usually play an active role, while offenders take meaningful responsibility for their actions, providing opportunities to right their wrongs and redeem themselves (McCold, 1996; Wemmers, 2002). In the context of service failure reported through eWOM, the review site acts as a mediating platform between consumers and hotels (Claffey \& Brady, 2014). Consumers actively report service failures on the review sites, with the expectation that the hotels will take responsibility for the failures and deliver fair outcomes to the consumers (Jeong \& Lee, 2017). Consumers express their satisfaction through evaluative judgements of the hotels' reactions, while hotels' satisfaction is measured by whether the recovery costs are deemed worthwhile (Chen, Ma, Bian, Zheng, \& Devlin, 2018). Another 
relevant feature of restorative justice is that each crime is personal and distinctive in terms of the offense level and the coordination and interaction during mediation need to be customized to accommodate the victims' appeals (Umbreit, Coates, \& Roberts, 2000). Similarly, in the service context, hotels need to differentiate reported service failures on the basis of their severity and tailor the responses to different cases (Kelley \& Davis, 1994).

This analogy reveals shared considerations of justice, similar mediation processes, and common personalised consideration between restorative justice and service recovery through eWOM. Restorative justice also offers tactical cues regarding conflict handling, which could provide useful reference points for developing cost-effective service recovery strategies. In adhering to the principle of cost-effectiveness, we adopt justice theory and its application in service and restorative justice research to guide the research design.

Following the concept of restorative justice, service recovery begins when a service provider embarks on a series of actions to restore dissatisfied consumers' perceptions. At this stage, the hotel strives to deliver justice to consumers who have given negative reviews through online communication. Justice in the service research context is usually considered a threedimensional concept, involving distributive justice, procedural justice, and interactional justice. Distributive justice refers to the perceived fairness of achieving the allocated benefits (Smith et al., 1999). In the service recovery setting, distributive justice represents the outcomes customers receive, which are often embodied by monetary compensation for failed services in the form of compensation, refunds, discounts, and coupons (Kim, Kim, \& Kim, 2009). Procedural justice in service research concerns the perception that the policies, procedures, and criteria used when delivering positive outcomes are fair (Blodgett, Hill, \& Tax, 1997). In practice, procedural justice is represented by service providers' speed of response to reported service failures (Liao, 2007). Interactional justice refers to how consumers are treated during the recovery process and is indicative of the perceived fairness of the interpersonal interaction during service recovery (Blodgett et al., 1997; Thibaut \& Walker, 1975). Interactional justice results when employees express interest in and concern with customers' experience and show empathy and courtesy in recovering failed services (Homburg, \& Fürst, 2005; Maxham \& Netemeyer, 2002).

In the context of service recovery for online review sites, when a hotel takes action, the expectation is that customers will be treated courteously and apologetically (i.e. delivering interactional justice) (Lewis \& McCann, 2004; McColl-Kennedy \& Sparks, 2003). Unlike in offline face-to-face service recovery, where physical cues (e.g. voice tone, facial expression and body language) could easily influence the customers' perceptions of interactional justice, 
service providers have comparatively more control over the delivery of interactional justice in the online environment, especially when standardised responses can be delivered (Blodgett et al., 997; Homburg \& Fürst, 2005; Singh \& Crisafulli, 2016). Thus, most studies on online service recovery have focused primarily on distributive and procedural justice (e.g. Crisafulli \& Singh, 2016).

\section{Hypotheses development}

We first examine whether hotels need to respond to negative reviews. Taking service failure severity into consideration, we then explore how hotels should respond to achieve the optimal recovery outcome. Finally, we evaluate chain effects of eWOM-mediated service recovery on consumers' eWOM engagement.

\subsection{Service recovery through eWOM}

Although negative eWOM poses new challenges, service failures reported through online reviews enable hotels to better understand and respond to the problems consumers encounter. After receiving a negative review, service providers need to decide whether to commence service recovery (Kim et al., 2015). A key consideration is that service failure can negatively influence consumers' evaluations of a consumption experience, their perceptions of the service provider, and their judgements of the recovery output (Liao, 2007; Wang, Wu, Lin, \& Wang, 2011). As the degree of impact is linked to the extent of the service failure, service providers need to judge the severity of the failure through the aggregated ratings and review comments provided (Dens, De Pelsmacker, \& Purnawirawan, 2015).

Prior research suggests that responding to consumer reviews brings positive benefits to hotels and is fundamental to managing customer relationships in the digital era (Chen \& Xie, 2008). Such responses can significantly influence hotels' online booking rates (Ye et al., 2008) and are positively associated with their performance (Xie et al., 2014). Surprisingly, the severity of service failure-that is, the perceived intensity of the problem that has occurred (McQuilken and Robertson, 2011; Weun, Beatty, \& Jones, 2004) — is not a prime consideration. For example, Mattila, Andreau, Hanks, and Kim (2013) show that providing personal responses to email complaints results in more favourable consumer attitudes than when no response is given, regardless of the service failure severity. Therefore, we expect that responding to consumers' negative reviews will always redeem their attitude towards the hotel (Huang, Mitchell, Dibner, Ruttenberg, \& Tripp, 2018). Thus: 
H1. Responding to negative reviews leads to more favourable consumer attitudes towards the hotel than offering no reply.

A service failure brings financial and psychological losses to customers. Several theories discuss customers' responses to losses and how they affect the internal evaluation of the consumption experience. Prospect theory claims that individuals are more attuned to losses than to gains and are less sensitive to the final outcome (Kahneman \& Tversky, 1979; Tversky $\&$ Kahneman, 1992). This suggests that the use of standardised recovery strategies for service failures with different severities will result in greater perceived losses for customers who have experienced severe service failures than for those who have experienced failures with relatively low severity. Similarly, mental accounting theory claims that when a service failure is followed by a recovery, consumers tend to perceive the losses from the failure as greater than the gains from the recovery (Thaler, 1985).

These theoretical foundations jointly support the notion that consumers assign more credence to the losses from service failures more than the benefits they receive during service recovery (Smith et al., 1999). Therefore, regardless of whether service recovery takes place, a severe service failure will always produce a perceived loss (Weun et al., 2004). Applying the principles of mental accounting theory, we suggest that if a hotel invests the same minimum "bundle of resources" into recovering service failures with different degrees of severity, consumers will perceive fewer net gains from the recovery effort associated with severe service failures than less severe failures. Thus, efforts to respond to severe service failure might be less likely to promote a favourable attitude towards the service provider than when responding to a less severe failure. In other words, if the failure severity is low, an identical level of recovery effort (e.g. the same compensation and an equally prompt response) is likely to yield greater returns because customers have made comparatively less sacrifice for the failure and are relatively more sensitive to the gains (Thaler, 1985). Thus:

H2. An identical amount of effort made in responding to online reviews that report less severe service failures has a stronger impact on consumers' attitude towards the hotel than responding to reviews that report more severe service failures. 


\subsection{Recovery strategy and recovery satisfaction}

When deciding to take restorative action to recover a reported service failure, service providers are likely to try to maximise the recovery output with the minimum investment of financial and human resources (Simons Jr \& Kraus, 2005; Yani-de-Soriano et al., 2019). Therefore, how the service provider responds to the negative review is critical to achieving the optimal recovery output. Research has widely adopted justice theory to predict customers' overall satisfaction with such remedial action, using the term "recovery satisfaction" to describe this outcome (Kuo \& Wu, 2012). Distributive and procedural justice can be manifested in monetary compensation and prompt response (Gelbrich \& Roschk, 2011; Liao, 2007), with both having a positive influence on consumer recovery satisfaction (e.g. Choi \& Choi, 2014; Hogreve, Bilstein, \& Mandl, 2017; Yeoh, Woolford, Eshghi, \& Butaney, 2014). Implementing both in practice requires the hotel to invest financial and human resources into the service recovery process. Considering the costs that can be incurred during service recovery, it is helpful to clarify the circumstances under which monetary compensation or prompt response is more important. However, the tradeoffs between different recovery strategies under different degrees of service failure have received only scant attention in the literature.

Given the synergies between restorative justice and service recovery, we can use theoretical propositions and empirical evidence from restorative justice research to shed light on the dilemma hotels face in developing cost-effective recovery strategies. Service scholars suggest that consumers require different levels of recovery to restore perceived justice and satisfaction, depending on the degree of service failure (Conlon \& Murray, 1996; Liao, 2007; Smith et al., 1999). Similarly, restorative justice studies claim that the needs and appeals of victims vary depending on the extent of harm done (Bolívar, 2013; Daly, 2005). This is analogous to criminal justice, in which the origins of restorative justice lie; in the case of a minor crime, material compensation is useful in helping the victim recover from the trauma, while such reparation cannot compensate the victim when the crime is severe (Sharp, 2007). For severe crime involving irretrievable losses, compensation becomes symbolic, and victims' appeals largely pertain to their emotional needs (Retzinger \& Scheff, 1996; Wemmers, 2002).

Chapman and Chapman (2016) argue that when a crime is severe, victims need to be heard with respect, treated sensitively, and responded to in a timely manner, thus allowing them to evaluate the perceived justice and judicial decision. The same logic applies to service failure and service recovery. When severe service failure leads to unrecoverable losses (Weun et al., 2004), consumers' perceived justice is affected by the time gap between their leaving a negative online review and receiving a response from the service provider (i.e. perceived procedural 
justice) and also by the way they are treated by the service provider (i.e. perceived interactional justice) (Crisafulli \& Singh, 2017; Bacile, Wolter, Allen, \& Xue, 2018).

Consumers always expect their voices to be heard, negative eWOM to be acknowledged, and an appropriate response to be provided by the service provider (Karande, Magnini, \& Tam, 2007). When differentiating consumers' appeals on the basis of the service failure severity, a prompt response is likely to contribute more to the recovery outcome than compensatory rewards when the service failure severity is high (Chapman \& Chapman, 2016). By contrast, reparation has a stronger impact on recovering less severe service failures, due to the greater salience of customers' material-oriented needs (Sharp, 2007). Accordingly, the impact of monetary compensation and prompt complaint handling on recovery satisfaction is a function of the service failure severity. Thus:

H3. When the perceived service failure severity is low, monetary compensation has a stronger positive influence on recovery satisfaction than a prompt response.

H4. When the perceived service failure severity is high, a prompt response has a stronger positive impact on recovery satisfaction than monetary compensation.

Oliver (1981) claims that (dis-)satisfaction gradually shapes attitudes towards products, services, and organisations. This type of attitude comprises positive or negative feelings and evaluations that are directed at a given object—in this case, the hotel (Lutz, 1991). Oliver (1987) further argues that satisfaction is divided into primary satisfaction (service received) and secondary satisfaction (service recovery). Primary satisfaction refers to consumers' emotional status and their evaluations of the consumption experience, while secondary satisfaction indicates their cognitive and emotional judgements of the recovery effort following a complaint (Oliver, 1981, 1987). Both primary and secondary satisfaction influence consumers' evaluative judgements of their attitudes towards the service provider (Oliver, 1987). Similarly, Boshoff (1997) finds that a service provider's effort in recovering dissatisfied consumers influences not only consumers' perceptions of secondary satisfaction but also their attitudes towards the service provider through recovery satisfaction. Mostafa, Lages, Shabbir, and Thwaites (2015) also argue that attitudes towards the service provider are positively affected by recovery satisfaction and reflects consumers' sense of perceived justice. Thus:

H5. Recovery satisfaction positively influences the attitude towards the service provider. 


\subsection{Online service recovery and future eWOM media engagement}

When consumers share eWOM on a review site, they expect their voices to be heard and not ignored (Wu, Mattila, Wang, \& Hanks, 2016). In the post-complaint stage, a hotel's responsiveness reflects the efficiency of reporting service failures through the complaint management system (Filip \& Anghel, 2009). Therefore, taking no recovery action in response to negative online reviews will influence not only consumers' evaluations of the service provider but also their eWOM continuance intention on the review sites.

Social approval theory suggests that individuals want to be liked and accepted by others (Aronson, Wilson, \& Akert, 2015). In the post-sharing phase, the attention and reaction that consumers receive from the service provider and other consumers as a result of sharing their views can reinforce the effort made in providing the eWOM(Lin \& Kalwani, 2018; Zhu, Yin, $\& \mathrm{He}, 2014)$. Such online social interaction positively influences consumers' behavioural engagement with the platforms they share (Hennig-Thurau, Gwinner, Walsh, \& Gremler, 2004; Yeh \& Choi, 2011). Therefore, in addition to the effect on attitude towards the service provider, the provider's review site response influences consumers' future engagement with such sites (Zhao \& Lu, 2012).

Executing customer recovery by replying to online reviews represents a higher level of perceived responsiveness than taking no action, regardless of the level of effort made and the severity of the service failure. When a service provider responds to negative reviews, consumers are likely to believe that their voices are valued and therefore are more likely to continue to contribute reviews. Song and Zinkhan (2008) suggest that the perceived responsiveness and interactivity of a site also positively influences consumers' evaluations of the site's usefulness and determines future engagement. Thus:

H6. A hotel responding to negative online reviews leads consumers to have higher future eWOM continuance intentions on the same review site than when offering no response.

When the service provider makes a restorative effort by responding to negative consumer reviews, the outcome of the service recovery may also affect consumers' future eWOM behavioural patterns. According to social exchange theory, consumers conduct a costbenefit analysis in deciding whether or not to perform certain behaviours. Satisfactory service recovery outcomes enhance the perceived material and psychological benefits of providing online reviews, which might then motivate the consumers to engage further in eWOM communication (Kim et al., 2009; Ro \& Wong, 2012). After all, higher recovery satisfaction 
implies a better service recovery experience associated with more perceived benefits (Al-Jader, 2015). Consumers who are more satisfied with their service recovery experience are likely to give eWOM review feedback more regularly, perhaps leading to habitual behaviour. Thus:

H7. Satisfaction with the hotel's service recovery effort positively influences consumers' future eWOM continuance intentions on the same review site.

Through the theoretical lens of restorative justice and the rationalization of the relationships, we outline the linkages between the individual concepts in our conceptual framework (see Fig. 1).

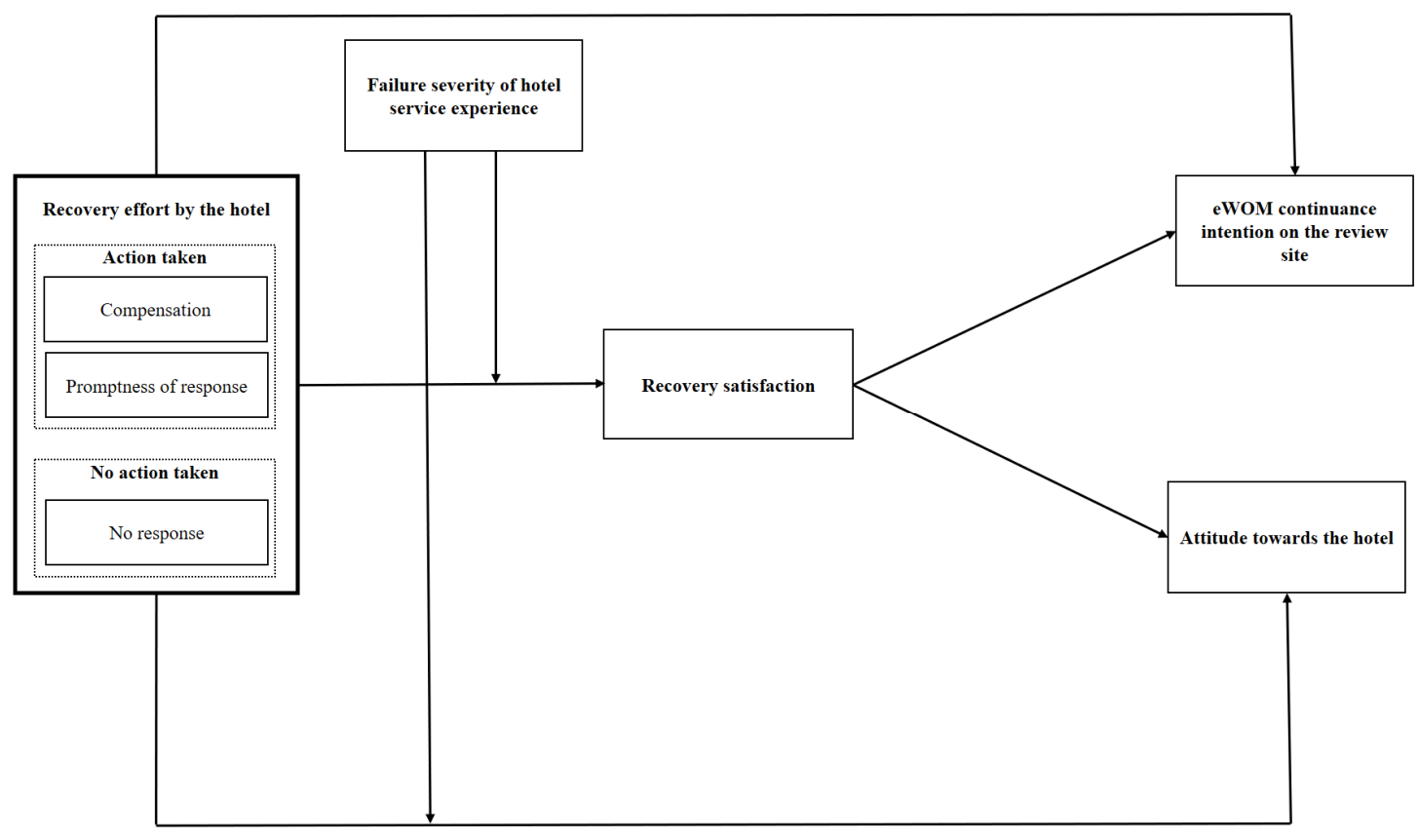

Fig. 1. Conceptual framework: How eWOM-triggered service recovery affects attitude towards the hotel and behavioural engagement with the review site.

\section{Method}

To address the research objectives, we devised a scenario-based experiment, a widely employed approach in service research (e.g. Blodgett et al., 1997; Liao, 2007) that is particularly suited to exploring negative consumption experiences (Bitner, 1990; Bitner, Booms, \& Tetreault, 1990). In addition to overcoming issues of recall bias related to self- 
reporting techniques, this approach provides an enhanced level of control in manipulations (Smith et al., 1999).

The experiment followed a 2 (service failure severity: low vs. high) $\times 2$ (monetary compensation: no coupon vs. coupon) $\times 2$ (speed of response: slow response vs. prompt response) between-subject design. Under the two levels of service failure severity, we added a "no-response" condition to the experimental design for comparison with alternative response conditions. From a managerial perspective, a coupon represents the most cost-efficient means of compensating customers among all types of monetary compensation (Mueller, Palmer, Mack, $\&$ McMullan, 2003). The reason is that service providers do not need to sacrifice any resources unless the customer chooses to use the coupon for a revisit. This experimental design minimized the inefficient use of resources and allowed the provision of coupons as monetary compensation to be examined. Thus, we manipulated the level of monetary compensation as yes/no instead of high/low (Mattila \& Cranage, 2005; Mattila \& Patterson, 2004; Wirtz \& Mattila, 2004). In adherence to the cost-effective principle, the monetary reward was embodied through a coupon. In addition to being a common form of compensation through which distributive justice is delivered in service recovery, coupons are a promotional tool that can boost consumers' future purchase intention (Hoffman, Kelley, \& Rotalsky, 1995; Kendrick, 1998). Hotel operators also largely regard coupons as a practical, easy-to-allocate reward (Hocutt \& Bowers, 2005).

\subsection{Simulation materials}

Participants were randomly assigned a description of either a "low" negative or a "highly" negative hotel stay experience (three nights' stay for holiday) to trigger their perception of service failure at low and high levels, respectively. Two similar-length vignettes each described a consumption experience at the fictitious three-star Diamond Hotel. The three key aspects of hotel services covered were the building/bedroom, furniture/equipment, and services. A three-star hotel was selected in the scenario because it is most likely to be accepted by the general public and therefore means the participants are more likely to engage with the scenarios (Shanka \& Taylor, 2004). We used three-star hotel criteria based on the standards of Expedia and Hotelstars Union for reference and expectation-setting purposes.

To enhance realism and facilitate participants' engagement, we chose Orlando as the hotel location in the scenario. Orlando is a popular holiday destination on the U.S. East Coast (Gollan, 2015). Participants, who were randomly assigned to one of 10 conditions, were asked to imagine that they had reported the experienced service failure through an online review on 
TripAdvisor. Eight out of the 10 conditions were descriptive accounts of the service provider's response and recovery effort to the participant's online review. We manipulated the monetary compensation and speed of response at different levels through coupon giving (one night's free stay vs. no coupon) and the timeliness of the recovery process (response within two days vs. response within two weeks). When there was no reply (two control conditions), participants were informed that the service provider did not respond to their online review (for details of three of the 10 stimulated scenarios, see Appendix A).

\subsection{Pretest}

We conducted a pretest to perform realism and manipulation checks before the main data collection and to ensure that the scenarios were realistic and believable and that the independent variables were successfully manipulated in the stimulus materials (Blodgett et al., 1997). We recruited an online panel to participate in this pretest, through which we collected 239 completed surveys. Fifteen respondents failed the comprehension questions in the manipulation checks, which left 224 valid responses. As social media use can directly influence consumers' eWOM engagement, we asked a series of filter questions about eWOM experience and social media use at the outset of the experiment. Twenty-three participants were filtered out without being invited to complete the survey due to their limited eWOM experience. This process ensured that the respondents could reasonably imagine themselves in the scenarios described and provide responses that reflected their true perceptions (Zhang, Abound Omran, $\&$ Cobanoglu, 2017). We removed those who reported having limited eWOM and social media experience from the sample.

\subsubsection{Realism checks}

The participants were asked to read the scenarios and rate their feelings on how realistic the scenario was (experimental realism) and how likely it was that the situation could happen in real life (mundane realism) (Liao, 2007; Roschk \& Kaiser, 2013). Seven-point Likert scales were employed to assess the experimental and mundane realism of the experimental design. Hair, Black, Babin and Anderson (1998) suggest each experimental condition should include at least five participants to ensure the validity of the experimental design. To enhance the reliability and generalizability of the realism checks, we went beyond the minimum requirement and recruited at least 20 participants in each experimental condition. We conducted one sample t-test (test value $=4$ ) for all experimental conditions. The realism checks 
(Table 1) indicated that the situations in the scenarios were experimentally and mundanely realistic (t-values > 1.96, p < .05) (Chawdhary \& Dall'Olmo Riley, 2015; Field, 2009).

Table 1. Results of realism checks.

\begin{tabular}{|c|c|c|c|c|}
\hline Scenario & $\begin{array}{l}\text { Experimental } \\
\text { realism (mean) }\end{array}$ & t-value & $\begin{array}{l}\text { Mundane } \\
\text { realism (mean) }\end{array}$ & t-value \\
\hline \multicolumn{5}{|l|}{$\begin{array}{l}\text { Low service failure } \\
\text { severity }\end{array}$} \\
\hline $\begin{array}{l}\text { Prompt response with } \\
\text { compensation }(n=27)\end{array}$ & 5.22 & $3.70 *$ & 5.30 & $3.55^{*}$ \\
\hline $\begin{array}{l}\text { Slow response with } \\
\text { compensation }(n=20)\end{array}$ & 5.75 & $6.25 *$ & 5.95 & $7.61 *$ \\
\hline $\begin{array}{l}\text { Prompt response without } \\
\text { compensation }(n=24)\end{array}$ & 4.90 & $2.19 *$ & 5.57 & $4.69 *$ \\
\hline $\begin{array}{l}\text { Slow response without } \\
\text { compensation }\end{array}$ & 5.83 & $7.05 *$ & 6.04 & $8.36 *$ \\
\hline No response $(\mathrm{n}=21)$ & 5.43 & $3.47 *$ & 6.10 & $6.81 *$ \\
\hline $\begin{array}{l}\text { High service failure } \\
\text { severity }\end{array}$ & & & & \\
\hline $\begin{array}{l}\text { Prompt response with } \\
\text { compensation }(n=21)\end{array}$ & 5.38 & $3.89 *$ & 6.05 & $9.64 *$ \\
\hline $\begin{array}{l}\text { Slow response with } \\
\text { compensation }(n=22)\end{array}$ & 5.18 & $3.30 *$ & 5.04 & $2.63 *$ \\
\hline $\begin{array}{l}\text { Prompt response without } \\
\text { compensation }(n=23)\end{array}$ & 5.65 & $7.40 *$ & 5.87 & $7.37 *$ \\
\hline $\begin{array}{l}\text { Slow response without } \\
\text { compensation }(n=20)\end{array}$ & 5.60 & $5.00 *$ & 5.65 & $6.24 *$ \\
\hline No response $(\mathrm{n}=25)$ & 5.20 & $4.43 *$ & 5.08 & $3.91 *$ \\
\hline
\end{tabular}

* t-values > 1.96; $p<.05$ (Field, 2009).

\subsubsection{Manipulation checks}

We measured service failure severity using scales adopted from Hess, Ganesan, and Klein (2003). Three 7-point semantic scales required the participants to rate whether the service failure was "severe," "major," or "significant" in the stimulus material ( $\alpha=.89$; Hess et al., 2003). An independent t-test demonstrated the effectiveness of the manipulation checks in service failure severity $\left(M_{\text {high }}=5.88, \mathrm{SD}=1.28\right.$ vs. $M_{\text {low }}=3.47, \mathrm{SD}=1.42 ; t(222)=-13.31, p$ $<.001)$. 
The control condition instead asked the participants, "In the scenario above, did you receive response from the hotel after leaving an online review?" (yes/no). Only three of the 239 participants failed to answer this question using the response conditions in the scenarios to which they were allocated. The $98.7 \%$ accuracy suggests that the response condition (with response vs. without response) was effectively manipulated. Participants allocated to the noresponse conditions were not required to complete the other manipulation questions.

We manipulated monetary compensation by whether the scenario included coupon giving. Three questions, displayed sequentially, examined the manipulation of monetary compensation: "Were you given any monetary compensation by the hotel?" (yes/no), "Which type of monetary compensation did you get from the hotel?" (discount/coupon/refund), and "How much is the face value of the coupon?" (one night's stay/two nights' stay/three nights' stay). Participants in the "no-response" conditions were directed to the manipulation questions. Only 12 of the 236 participants failed to provide answers that matched their assigned scenarios. The accuracy rate for this set of questions was $95 \%$, suggesting that the manipulation of monetary compensation was effective.

We measured speed of response on a single-item 7-point Likert scale adopted from Liao (2007): "According to the scenario, the hotel reacts promptly to your online review." An independent t-test indicated that the response speed was effectively manipulated in the stimulus materials $\left(M_{\text {prompt_response }}=5.09, \mathrm{SD}=1.47\right.$ vs. $M_{\text {slow_response }}=2.92, \mathrm{SD}=1.27 ; t(176)=11.47$, $p<.001)$.

\subsection{Data collection procedure}

Following the successful manipulations and realism checks, we used the same data collection technique and selection criteria for the main study. We recruited an additional 360 participants (59.7\% female, aged 18-80 years). The dependent variables included attitude towards the service provider ( $\alpha=.95$; Rodgers, 2003), recovery satisfaction ( $\alpha=.93$; Roschk $\&$ Kaiser, 2003), and eWOM continuance intention $(\alpha=.89$; Lee, 2010). After reading the hotel stay scenario, participants rated their experience on a 5-point scale ranging from terrible (1) to excellent (5), similar to that used by TripAdvisor. This rating was useful in helping diagnose the perceived severity of the service failure in the eWOM context. Appendix B provides the questionnaire. 


\section{Analysis and results}

To evaluate whether responses to the negative review always contributed to building a more favourable attitude towards the hotel compared with no response, we re-classified the data into no-response and with-response conditions. These conditions included four subconditions based on the manipulation of monetary compensation and speed of response. The analysis of variance (ANOVA) showed that response status had a significant effect on attitude, regardless of the service failure severity $(F(4,355)=7.20, p<.001)$. In the with-response conditions, the sub-condition with no compensation and slow response speed led to the lowest mean value in attitude (see Fig. 2). A comparison of mean values indicates that there is no significant difference between the no-response and with-response conditions ( $M_{\text {no-response }}=2.42$, $\mathrm{SD}=1.62$ vs. $\left.M_{\text {slow_response_without_compensation }}=2.84, \mathrm{SD}=1.44 ; t(142)=1.62, p>.05\right)$. Thus, $\mathrm{H} 1$ is rejected.

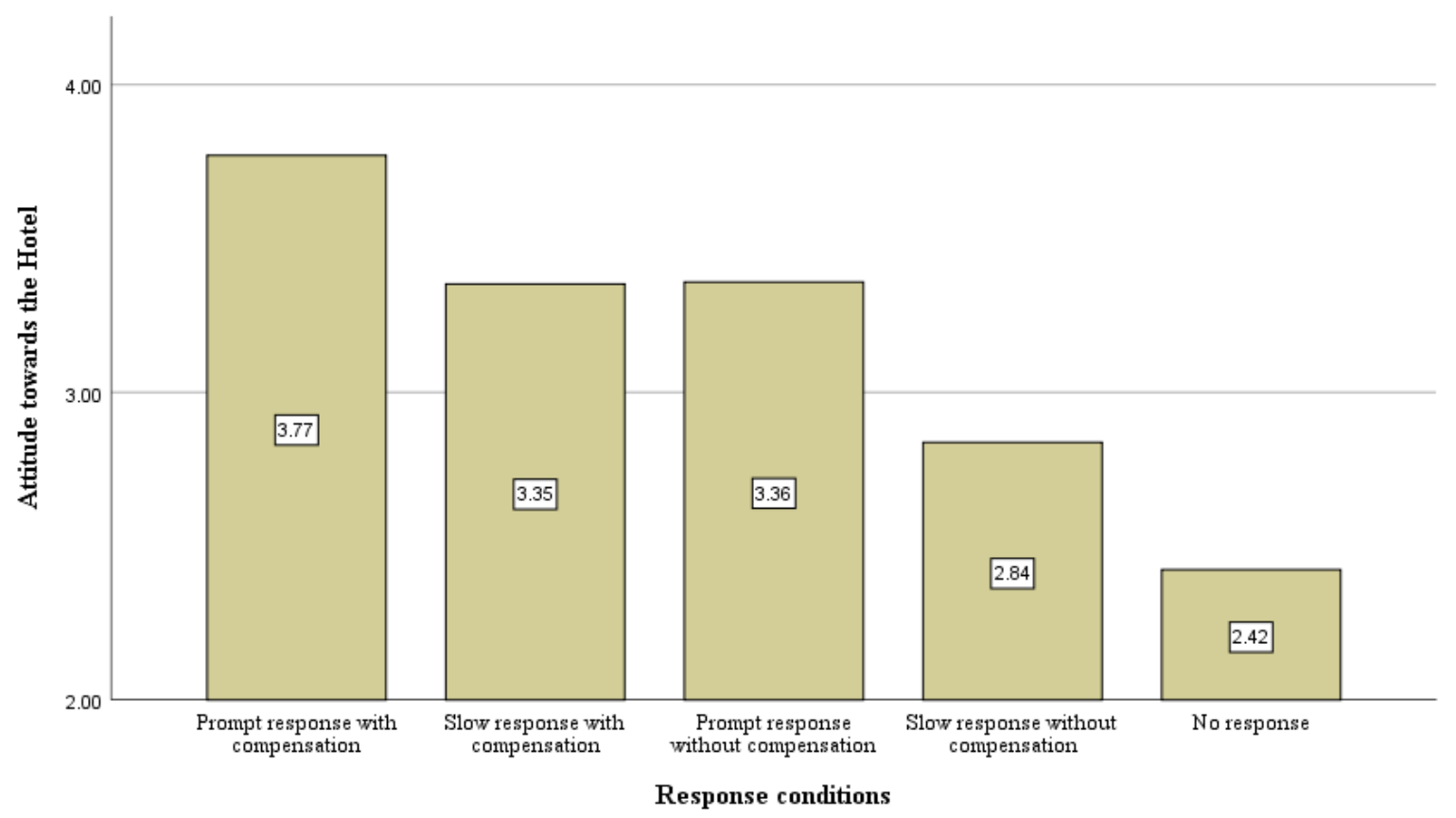

Fig. 2. Attitude towards the hotel by response conditions.

To test the effects of giving a response under high and low service failure severity, ANOVA showed that response status had a significant effect on attitude under both high service failure severity $(F(4,173)=3.42, p<.05)$ and low service failure severity $(F(4,177)$ $=9.45, p<.001)$. When service failure severity was high, in the with-response conditions, the sub-condition with no compensation and slow response speed led to the lowest mean value in attitude. A comparison of mean values suggests that there is no significant difference between the no-response and with-response conditions $\left(M_{\text {no-response }}=2.06, \quad \mathrm{SD}=1.27\right.$ vs. 
$M_{\text {slow_response_without_compensation }}=2.05, \mathrm{SD}=1.42 ; t(71)=-.03, p>.05 ;$ see Fig. 3). Similarly, responding to consumers' negative online reviews always led to more positive attitudes towards the service provider under low service failure severity $\left(M_{\text {no-response }}=2.80, \mathrm{SD}=1.29\right.$ vs. $M_{\text {prompt_response_without_compensation }}=3.47, \mathrm{SD}=1.39 ; t(70)=2.12, p<.05 ;$ see Fig. 3 ). Therefore, $\mathrm{H} 2$ is supported.

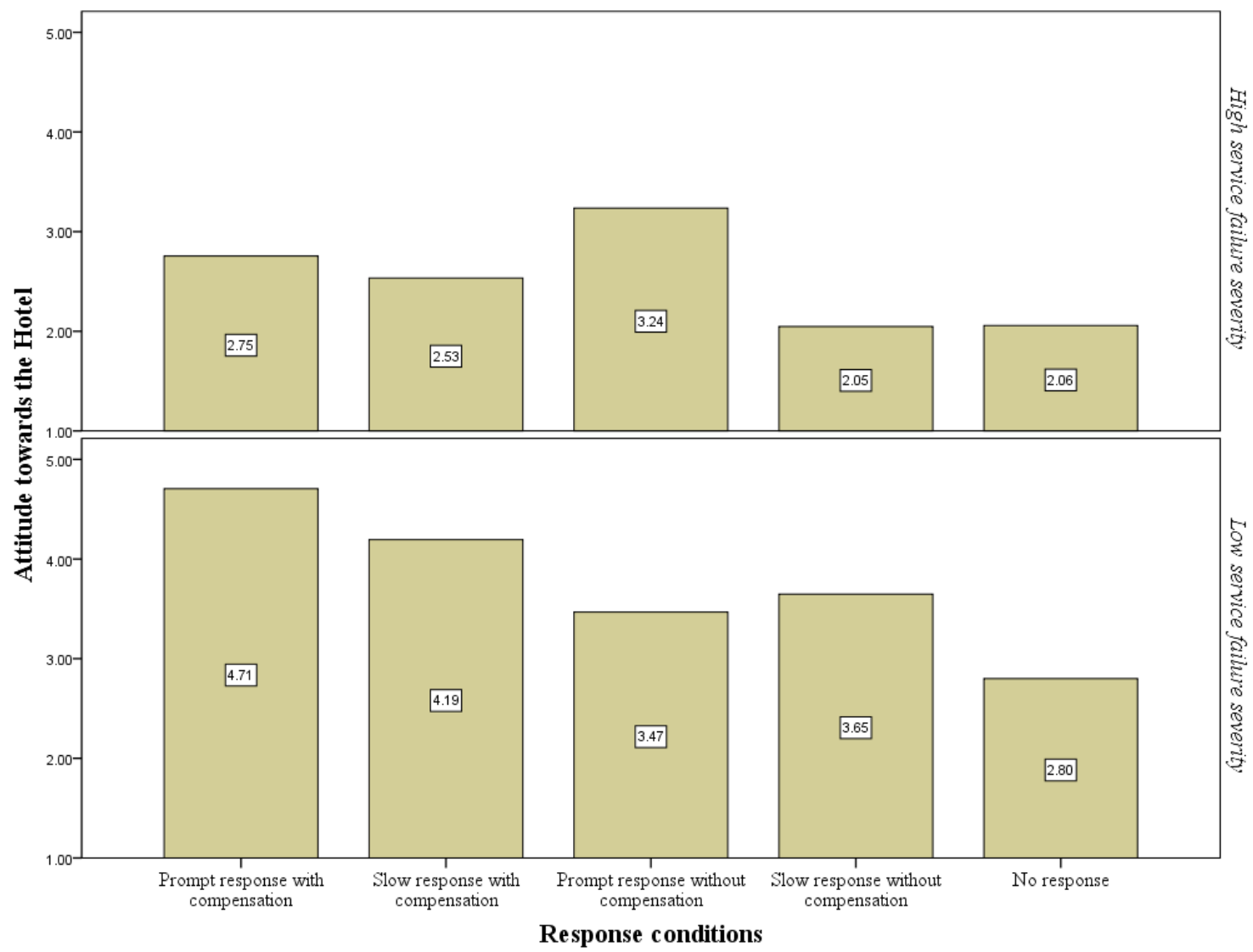

Fig. 3. Attitude towards the hotel under high and low service failure severity by response conditions.

To evaluate the effects of monetary compensation and speed of response in the conditions of high service failure severity, we employed a two-way ANOVA. Under less severe service failure, in which both compensation condition and response speed condition are available, monetary compensation $(F(1,177)=46.78, p<.001)$ had a more significant influence on consumers' recovery satisfaction than speed of response $(F(1,177)=3.71, p>.05)$. As the monetary compensation had more significant effects on recovery satisfaction than speed of response when service failure severity is low, H3 is supported. Similarly, the two-way ANOVA results showed that monetary compensation had no significant effect on participants' recovery satisfaction $(F(1,173)=2.99, p>.05)$, while the effect of speed of response was significant $(F(1,173)=6.38, p<.05)$. Therefore, $\mathrm{H} 4$ is supported. In addition, the regression 
analysis showed that recovery satisfaction positively influenced consumers' attitudes towards the service provider $(F(1,289)=455.52, p<.001)$, lending support to H5.

Moreover, the ANOVA showed that response status significantly influenced consumers' eWOM continuance intentions $(F(4,355)=5.21, p<.001$; see Fig. 4). A comparison between the no-response condition and the lowest sub-condition (slow response without compensation) in the with-response condition showed that a response led to significantly greater eWOM continuance intentions than no response $\left(M_{\text {no-response }}=4.38, \quad \mathrm{SD}=1.49 \mathrm{vs}\right.$. $\left.M_{\text {slow_response_without_compensation }}=4.86, \mathrm{SD}=1.41 ; t(70)=1.95, p<.05\right)$. Therefore, $\mathrm{H} 6$ is supported. Finally, linear regression identified a positive association between recovery satisfaction and consumers' eWOM continuance intention $(F(1,289)=4.44, p<.05)$. Thus, $\mathrm{H} 7$ is supported.

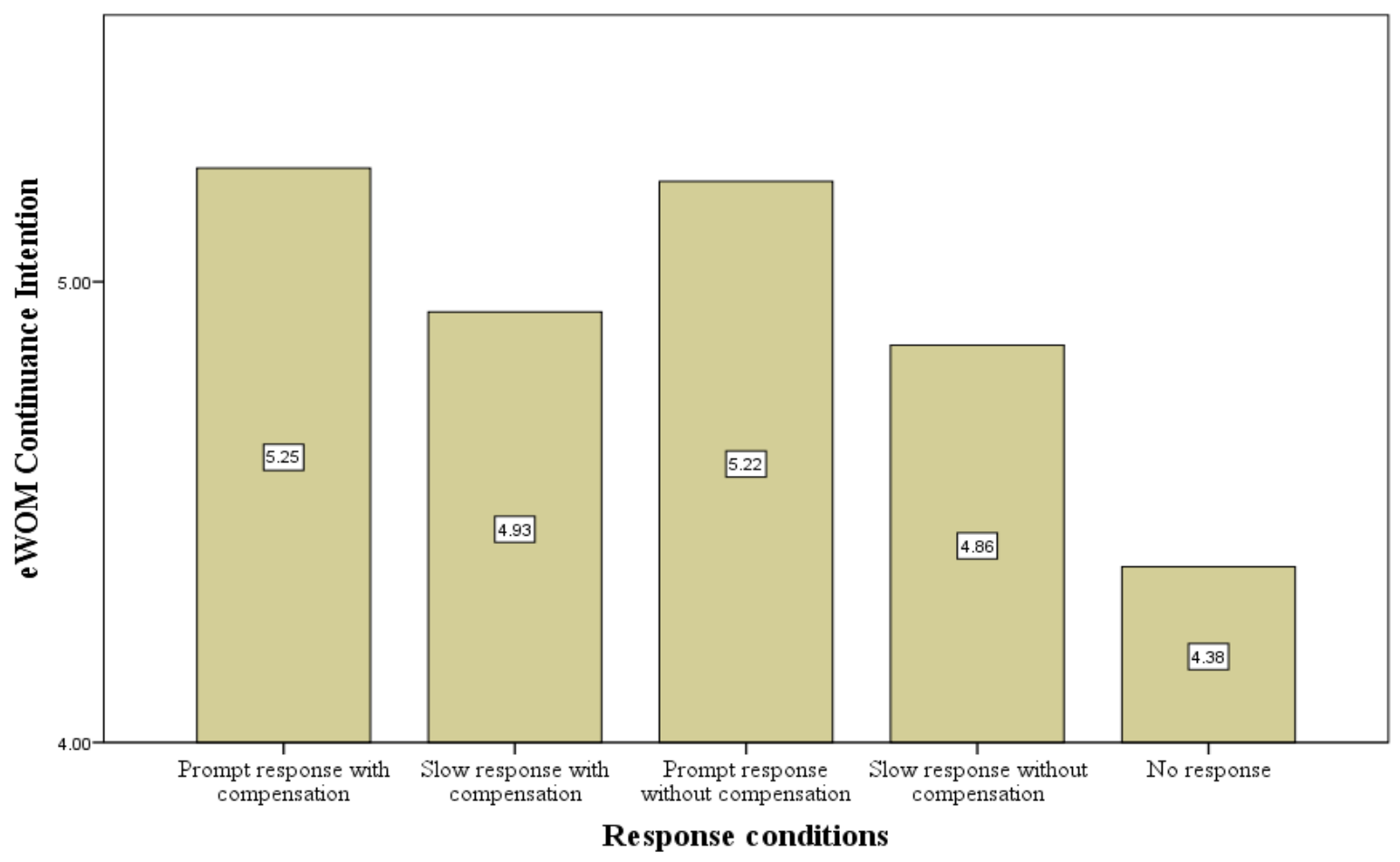

Fig. 4. eWOM continuance intention by response conditions.

In addition, $93 \%$ of participants (166 of 178) who experienced severe service failure gave a rating of 1 out of 5 (terrible, $M=1.13$ ), while $78 \%$ (142 of 182) who experienced failed service with low severity gave a rating of 2 (poor, $M=2.34$ ). In summary, H2, H3, H4, H5, H6, and H7 were accepted, while H1 was rejected. 


\section{Discussion}

We set out to investigate how and in what ways service operators should respond to negative consumer reviews. Our inquiries result in several academic and managerial contributions.

\subsection{Theoretical implications}

Our study provides the first empirical examination of service providers' online service recovery strategies and outcomes through the theoretical lens of restorative justice. By investigating the propositions of restorative justice in a service recovery context, we confirm that the essence of justice theory can be transferred to other disciplines. Our findings have important implications for service researchers wanting to extend the theoretical basis in conventional service failure studies. The specific emphasis on service failure severity gives form to previous propositions and findings regarding the causal relationships between different recovery strategies and consumers' evaluation of recovery outcomes. We thus highlight the significance of developing customized service recovery tactics to accommodate customers' different appeals resulting from distinctive severities of service failures. Applying the restorative justice concept to the tradeoff between monetary compensation and speed of response brings fresh insights to the debate. While previous studies have identified the overall positive impact of monetary compensation and speed of response on the recovery outcome (e.g. Kim et al., 2009; Smith et al., 1999), we suggest a more nuanced strategy, in which the implementation of monetary compensation and prompt response depends on the severity of the reported service failure. Thus, our findings contribute to understanding the mechanism of justice delivery in different circumstances of service failures.

Moreover, we rationalize the service recovery process in the context of eWOM, which conceptualizes the feasibility of complaint handling on third-party online review sites. Drawing upon the ideas from restorative justice, we show the review site plays a mediating and coordinating role in the conflict-resolution process. Our findings also suggest that service providers' handling of present negative online reviews has a chain effect on consumers' future behaviours, influencing both recovery satisfaction with the hotel and the consumers' future engagement with online media. This finding identifies media engagement as a new dimension of the output of eWOM-triggered service recovery. 


\subsection{Managerial implications}

Our study also has important implications for practice, especially in helping marketing practitioners develop the most cost-effective customer recovery strategies. First, unlike most previous studies that suggest that service providers should always respond to consumers' complaints, we find that the efficiency of hotels' responsiveness is a function of service failure severity. Minimum recovery effort made in response to consumers' complaints is just as insignificant as being unresponsive when service failures are severe. To achieve desirable recovery outputs under different situations, cost-effective service recovery strategies that optimise the use of financial (e.g. providing compensatory rewards) and human (e.g. responding promptly) resources are necessary. More precisely, our findings reveal that the restorative steps that hotels take should depend on the severity of the service failure reported on review sites. Adhering to the cost-effective principle, when resources are limited, responding to online reviews is likely to be more efficient when the severity of failure is low rather than high. After all, hotels are likely to have to pay a much higher price to recover consumers who experience severe service failure, with little or no possibility of achieving desirable outcomes. The minimum effort from the hotel in this scenario costs resources but cannot rescue the damage created in consumers' minds. Therefore, hotels with limited resources are encouraged to prioritise their resources to respond to the reviews that report less service failures and, at the same time, we highlight the utility of remaining unresponsive for the severe service failures reported in the reviews. Whether or not hotels respond to the negative reviews could also depend on strategic intent. Hotels that have reputation-oriented strategic intent should proactively and energetically respond to all negative reviews in order to build and sustain a positive brand image. In contrast, profit-oriented strategic intent could lead to a costsaving focus that may not support the additional effort in recovering the failed service, particularly when the service failure is severe.

Second, our findings indicate that managers should take the severity of a service failure into account when dealing with failures reported in negative online reviews. The aggregated ratings and review content provided by consumers could play a diagnostic role in helping service providers determine the severity of the reported service failure. Having a system to judge service failure severity could also lead to more cost-effective strategies. As we have shown, monetary compensation leads to higher recovery satisfaction than prompt response when the service failure severity is low, while prompt handling arouses higher recovery satisfaction under severe service failure. Identifying how severely consumers perceive the service failure is therefore critical. 
A simple approach might be for hotels to use the TripAdvisor-style 5-point rating system as a service failure diagnostic. When consumers rate the hotel-staying experience as 1 out of 5 points (terrible), the hotel could assume the service failure is severe and adopt a procedure-oriented recovery strategy to address it. When consumers rate the experience as 2 out of 5 (poor), lower severity might be implied, with the hotel adopting a compensationoriented strategy. An "average" rating of 3 out of 5 might also reflect a minor service failure. In this case, hotel managers should read the content of the reviews to better understand the service failure severity and decide whether a compensation-oriented strategy is appropriate. During the post-recovery stage, recovery satisfaction is positively associated with attitude towards the service provider when customer recovery takes place. Therefore, service providers could restore the stigmatised image through "reversing" and "re-satisfying" customers who experienced service failures in the service recovery.

Third, our findings show that consumers have higher eWOM continuance intentions when service providers are responsive to negative online reviews. When consumers believe that their opinions are valued and acknowledged by the hotel, they perceive their contributions to the site as more meaningful (Zheng, Zhao, \& Stylianou, 2013). Moreover, when service providers make a recovery effort, higher recovery satisfaction is likely to evoke higher intentions to continue with eWOM (Schlosser, 2003). The media owners of review sites should encourage service providers to support the sites' interactivity by engaging with consumers who give negative online reviews.

Some firms in the hospitality industry are de-motivated to reply to negative reviews, as a lower rating is counted in their profiles and also permanently available on the review sites (Pentina, Basmanova, Zhang, \& Ukis, 2015). Just as civil mediation officers are involved in supporting restorative justice, media owners should take more responsibility in mediating the conflict between hotels and consumers to improve satisfaction on both sides (Umbreit, 1994; Umbreit et al., 2004). Review and booking sites could consider developing a trouble-shooting review system that evaluates consumers' secondary satisfaction with their service providers. Such a system could motivate hotels to correct problems by offering them a meaningful chance to respond. As care would be necessary to avoid deliberate smears and bargain hunting (Casarez, 2002; Chong, Ch'ng, Liu, \& Li, 2015), this service could be made available only to consumers who book on the review sites. This approach would make more information about the transaction available to review sites, enabling them to better play the mediating role. Such a trouble-shooting rating system might also enhance the booking rates on the review sites and become a viable source of competitive advantage. However, in the current stage, in which such 
systems are not yet available, we recommend that service providers give monetary compensation in a private manner to avoid consumers' unethical behaviours.

Because eWOM continuance intention was valence-free in this study, customers were able to continuously engage in both positive and negative eWOM sharing. Thus, being responsive to the negative reviews and achieving recovery satisfaction through strategic handling of the online reviews could be a double-edge sword for service providers. If customers are over-empowered by a hotel's recovery response, they might have unrealistic expectations of future eWOM-triggered service recovery. Conversely, having their voices heard when giving negative reviews could also encourage customers to engage in positive eWOM on the review site. Here, there is a key difference in service recovery between the online and offline environments. In the offline case, word of mouth elicited by service recovery tends to be directly solely at the provider of the failed service. In the eWOM case, other companies can potentially be affected by the service recovery efforts of these firms. For example, the service recovery efforts of one hotel could motivate a customer to review other service providers on the review site. Customers would also be able to make comparisons between service providers based on their responsiveness and effort (Allen, Brady, Robinson, \& Voorhees, 2015).

\subsection{Limitations and future research}

Although our study takes a novel approach to investigating the role of service severity, it has certain limitations that have implications for future research. First, monetary compensation is limited to the use of coupons in this study. Future research could examine the impact of other forms of compensation, such as discounts or refunds, in service recovery situations. Second, the scenario development in this study focuses on a three-star hotel, which may limit the generalizability of our findings. As customers may have different expectations towards different hotel types and categories, future research could compare the effectiveness of similar recovery strategies for luxury hotels and economy/budget hotels. Equally, future research should explore the impact of customer characteristics (e.g. gender, age and cultural background) and situational factors (e.g. purpose of travelling and size of travelling group) on the perceptions of service recovery outcomes. Such research would enable more tailored recovery strategies to be developed that fulfil the needs of multiple customer groups (McCollKennedy, Daus, \& Sparks, 2003). Third, the focus of our study was on achieving service recovery by responding to negative eWOM service failure reported on review sites. Future research could examine whether using customer retention strategies to respond to positive eWOM influences customers' evaluations of the consumption experience and leads to more 
positive outcomes for the hotel. Fourth, our findings suggest that hotel responsiveness and recovery effort can contribute to eWOM continuance intention and potentially lead to habitual eWOM behaviours (Taber, Black, Porrino, \& Hurley, 2012). The measurement of eWOM continuance intention in this study was valence-free. Future research could de-construct the eWOM construct by examining the influence of responses to both positive and negative online reviews on consumers' eWOM engagement and the formation of habitual behavioural patterns of eWOM giving. Fifth, this study emphasises the impact of hotels' recovery strategies on customers who reported service failures through eWOM. However, as the review sites are open access, other customers could view the hotels' responses. Further investigation of how different response styles influence potential customers' impressions and future purchase behaviour is necessary.

\section{Conclusion}

This study examines the necessity for and strategies of responding to negative online reviews that report different levels of service failures through the theoretical lens of restorative justice. In doing so, this study reveals the functional interactions between the cost of financial (i.e. compensatory) and human (i.e. promptness of response) resources, and the benefits (i.e. positive recovery outcomes) of responding to negative online reviews. We make several contributions to the theoretical and practical understanding of the tactics that service providers use to recover reported service failures in the online context. The findings suggest that being responsive to negative reviews through minimum recovery effort is feasible only when the reported failures are less severe. To achieve desirable recovery outcomes with limited resources, hotels should prioritise providing a timely response, rather than offering compensation, when the reported service failure is severe. When the service failure is less severe, responding promptly is less critical and providing compensation can be effective in addressing unfavourable attitudes towards the hotel. In addition, service providers' responsiveness influences customers' future engagement with eWOM media. Review sites could benefit from this enhanced involvement by playing a mediating role and motivating the dialogue between organisations and customers. 


\section{Appendix A: Stimuli}

Imagine that you are going to Orlando for a 5-day (4 nights) holiday with your partner (or best friend) during the summer time and staying in a hotel called Diamond Hotel that you booked about 6 weeks in advance. Diamond Hotel is recognized as a 3-star hotel on major hotel booking sites (e.g. Expedia, Hotels.com, Booking.com). You booked the hotel at the average rate of \$100/per night for a standard room.

\section{3-star hotel standard in scenarios}

\section{Building/rooms}

Clean and hygienic, and all mechanisms and equipment are functional and in a faultless condition.

\section{Furniture/equipment}

Toothbrush tumbler, soap or body wash, bath essence or shower gel, shampoo, cleansing tissue, and towels are available in the private bathroom. Double beds are a minimum of $1.80 \mathrm{~m} \times 1.90$ $\mathrm{m}$. Colour TV with a remote control and telephone. Internet access in the public area or in the rooms.

\section{Services}

Daily room cleaning. Breakfast buffet or equivalent breakfast menu card that includes at least one hot beverage, a fruit juice, fruit or a fruit salad, a choice of bread and rolls with butter, jam, cold cuts, and cheese. Most offer 24-hour reception service.

* Adopted from the criteria for Hotelstars Union and Expedia Star Ratings (hotel class). 
Service failure conditions

More severe service failure

During your stay, you found that ...

\section{Building/room}

The hotel looked dirty and poorly maintained from the outside. The whole building seemed damp, and a lot of mould was visible. The hotel room appeared small, and the carpet was covered with dust and hair.

\section{Furniture/equipment}

One corner of the built-in dressing mirror on the wardrobe was cracked. The bed looked smaller than the standard double-bed size, and the mattress was quite hard. The pillows that the hotel provided were too soft, and the hotel claimed that it did not have alternative pillows after you asked about this. The texture of the sheets and duvet cover was quite rough, and they had lightcoloured stains on them. A small TV was installed in the room but did not function at all. The Wi-Fi was available in public areas, but not in the room. The hotel provided no toiletries in the bathroom.

\section{Service}

The room was cleaned on the first two days. On the second two days, the room was only cleaned if required.

Only two tea bags and instant coffee sachets were available in the room, and these were not refilled after being consumed. The breakfast buffet was served from 7:00 A.M. to 10:00 A.M. with a very limited choice. A call to reception was not answered on the third night. A request to change the room was rejected out of hand. The reception staff worked rather inefficiently, and check-in and check-out took about 15 minutes. 


\section{During your stay, you found that ...}

\section{Building/room}

The hotel looked clean but dated from the outside. The whole building was neat but smelled slightly damp. The hotel room was clean but not very big.

\section{Furniture/equipment}

The wardrobe had a medium-sized built-in dressing mirror. The bed was standard in size, and the mattress felt very firm. The pillows the hotel provided were too soft, and the hotel claimed that it did not have alternative pillows after you asked about this. A small TV was installed in the room but with only a very limited number of free channels. The free Wi-Fi was quite slow, and the network was not very stable, as your electronic equipment occasionally lost the connection. The hotel provided some basic toiletries in the bathroom.

\section{Service}

The room was cleaned daily. Certain types of tea and coffee were re-filled daily, but no biscuits were offered. The breakfast buffet was served from 7:00 A.M. to 10:00 A.M. with a few different choices. Reception service was accessible $24 / 7$ by phone. The hotel staff were friendly but not very helpful. The reception staff worked quite slowly, and the waiting time at the reception was about 10 minutes at check-in and check-out. 


\section{Response conditions}

Response condition: Prompt response with coupon

Imagine that you wrote a review on TripAdvisor to complain about the negative experience you had at Diamond Hotel and that you received a reply after two days on TripAdvisor from the manager of Diamond Hotel, as follows:

\section{Dear guest}

Thank you very much for leaving us a review.

As the hotel manager, I take every guest's review of Diamond Hotel very seriously. As you were not fully satisfied with your stay with us, could you please contact us and provide your booking information. We will investigate the problems that you mentioned in your review and get back to you.

Our email address is: customerservice_dimondhotel@hotmail.com

Sincerely,

John Owens

Manager of Diamond Hotel

Now imagine that after providing your booking information as the hotel manager indicated, three days later, you have received the following email from the manager of Diamond Hotel.

\section{Dear guest}

Thank you for leaving us a review on TripAdvisor and contacting us with your booking information. Your feedback is important to us. I am very sorry to hear that you did not enjoy staying with us. I can totally understand your frustration as the experience did not live up to your expectations. After our careful investigation, we realized there were some real issues 
of our service with your stay. On behalf of the managerial team and our staff, I hope you will accept our sincere apologies for any inconvenience.

Meanwhile, we would like to offer you one night's free stay* that can be used anytime at Diamond Hotel. The e-coupon is attached in this email. I hope we can welcome you back to Diamond Hotel in the future.

Sincerely,

John Owens

Manager of Diamond Hotel

*Offer conditions:

-Valid for standard rooms (double or twin) only

-Advance booking is required for using the offer (48 hours in advance) 
Imagine that you wrote a review on TripAdvisor to complain about the negative experience you had at Diamond Hotel and that you received a reply after two weeks on TripAdvisor from the manager of Diamond Hotel as below.

\section{Dear guest}

Thank you very much for leaving us a review.

As the hotel manager, I take every guest's review of Diamond Hotel very seriously. As you were not fully satisfied with your stay with us, could you please contact us and provide your booking information. We will investigate the problems that you mentioned in your review and get back to you.

Our email address is: customerservice_dimondhotel@hotmail.com

Sincerely,

John Owens

Manager of Diamond Hotel

Now imagine that after providing your booking information as the hotel manager indicated, three weeks later, you have received the following email from the manager of Diamond Hotel.

Dear guest

Thank you for leaving us a review on TripAdvisor and contacting us with your booking information. Your feedback is important to us. I am very sorry to hear that you did not enjoy staying with us. I can totally understand your frustration as the experience did not live up to your expectations. After our careful investigation, we realized there were some real issues of our service with your stay. On behalf of the managerial team and our staff, I hope you 
could accept our sincere apologies for any inconvenience. I hope we can welcome you back to Diamond Hotel in the future.

Sincerely,

John Owens

Manager of Diamond Hotel 
Response condition: No response

Imagine that you wrote a review on TripAdvisor to complain about the negative experience you had at Diamond Hotel. After 5 weeks, Diamond Hotel has neither replied to your review on TripAdvisor nor contacted you via email. 


\section{Appendix B: Summary of measurement scales}

\section{Hotel rating}

How would you rate your experience with Diamond Hotel on TripAdvisor?

(Terrible/poor/average/good/excellent)

Attitude towards service provider ( $\alpha=.95$; Rodgers, 2003; 7-point semantic differential)

On the basis of my own experience with Diamond Hotel and how my review was dealt with, my overall impression of Diamond Hotel is:

$\mathrm{Bad} / \mathrm{good}$

Unfavourable/favourable

Unsatisfactory/satisfactory

Negative/positive

Disliked/liked

Recovery satisfaction ( $\alpha=.93$; Roschk \& Kaiser, 2003; 7-point Likert scale)

I am happy with my complaining review was handled.

In my opinion, the hotel manager provided a satisfactory solution to my complaint.

I am satisfied with the handling of my complaining review.

I am satisfied with how the hotel manager handled the problem in this particular occasion.

eWOM continuance intention ( $\alpha=.89$; Rodgers, 2003; 7-point Likert scale)

Based on the my overall experience with Diamond Hotel and how my review was handled, I will use TripAdvisor to share my hotel-staying experience on a regular basis in the future. I will frequently use TripAdvisor to share my hotel-staying experience in the future.

I will strongly recommend others to use TripAdvisor to share their hotel-staying experience. 


\section{References}

Al-Jader, R. (2015). Structural equation modeling of e-service recovery satisfaction and customer retention in the airline industry in Malaysia. International Journal of Marketing Studies, 7(4), 105-120. https://doi.org/10.5539/ijms.v7n4p105

Allen, A. M., Brady, M. K., Robinson, S. G., \& Voorhees, C. M. (2015). One firm's loss is another's gain: capitalizing on other firms' service failures. Journal of the Academy of Marketing Science, 43(5), 648-662. https://doi.org/10.1007/s11747-014-0413-6

Aronson, E., Wilson, T. D., \& Akert, R. M. (2015). Social Psychology (9th ed.). Boston, MA: Pearson/Allyn \& and Bacon.

Bacile, T. J., Wolter, J. S., Allen, A. M., \& Xu, P. (2018). The effects of online incivility and consumer-to-consumer interactional justice on complainants, observers, and service providers during social media service recovery. Journal of Interactive Marketing, 44, 60-81. https://doi.org/10.1016/j.intmar.2018.04.002

Bitner, M. J. (1990). Evaluating service encounters: The effects of physical surroundings and employee responses. Journal of Marketing, 54(2), 69-82. https://doi.org/10.1177/002224299005400206

Bitner, M. J., Booms, B. H., \& Tetreault, M. S. (1990). The service encounter: Diagnosing favorable and unfavorable incidents. Journal of Marketing, 54(1), 71-84. https://doi.org/10.1177/002224299005400105

Blodgett, J. G., Hill, D. J., \& Tax, S. S. (1997). The effects of distributive, procedural, and interactional justice on postcomplaint behavior. Journal of Retailing, 73(2), 185-210. https://doi.org/10.1016/S0022-4359(97)90003-8

Bolívar, D. (2013). For whom is restorative justice? A mixed-method study on victims and (non-) participation. Restorative Justice, 1(2), 190-214. https://doi.org/10.5235/20 $\underline{504721.1 .2 .190}$

Boshoff, C. (1997). An experimental study of service recovery options. International Journal of Service Industry Management, 8(2), 110-130. https://doi.org/10.1108/095642 $\underline{39710166245}$

Boshoff, C., \& Allen, J. (2000). The influence of selected antecedents on frontline staff's perceptions of service recovery performance. International Journal of Service Industry Management, 11(1), 63-90. https://doi.org/10.1108/09564230010310295

Cantallops, A. S., \& Salvi, F. (2014). New consumer behavior: A review of research on eWOM and hotels. International Journal of Hospitality Management, 36, 41-51. https://doi.org/10.1016/j.ijhm.2013.08.007

Casarez, N. B. (2002). Dealing with cybersmear: How to protect your organization from online defamation. Public Relations Quarterly, 47(2), 40-45.

Chan, N. L., \& Guillet, B. D. (2011). Investigation of social media marketing: How does the hotel industry in Hong Kong perform in marketing on social media websites?. Journal of Travel \& Tourism Marketing, 28(4), 345-368. https://doi.org/10.1080/10548408. 2011.571571

Chapman, T., \& Chapman, A. (2016). Forgiveness in restorative justice: Experienced but not heard?. Oxford Journal of Law and Religion, 5(1), 135-152. https://doi.org/10.109 3/ojlr/rwv066

Chawdhary, R., \& Dall'Olmo Riley, F. (2015). Investigating the consequences of word of mouth from a WOM sender's perspective in the services context. Journal of Marketing Management, 31(9-10), 1018-1039. https://doi.org/10.1080/0267257X.2015.1033443

Chebat, J. C., \& Slusarczyk, W. (2005). How emotions mediate the effects of perceived justice on loyalty in service recovery situations: An empirical study. Journal of Business Research, 58(5), 664-673. https://doi.org/10.1016/j.jbusres.2003.09.005 
Chen, T., Ma, K., Bian, X., Zheng, C., \& Devlin, J. (2018). Is high recovery more effective than expected recovery in addressing service failure? - A moral judgment perspective. Journal of Business Research, 82, 1-9. https://doi.org/10.1016/j.jbusres.2017.08.025

Chen, Y., \& Xie, J. (2008). Online consumer review: Word-of-mouth as a new element of marketing communication mix. Management Science, 54(3), 477-491. https://doi.org/10.1287/mnsc. 1070.0810

Choi, B., \& Choi, B. J. (2014). The effects of perceived service recovery justice on customer affection, loyalty, and word-of-mouth. European Journal of Marketing, 48(1/2), 108131. https://doi.org/10.1108/EJM-06-2011-0299

Chong, A. Y. L., Ch'ng, E., Liu, M. J., \& Li, B. (2017). Predicting consumer product demands via Big Data: The roles of online promotional marketing and online reviews. International Journal of Production Research, 55(17), 5142-5156. https://doi.org/10.1080/00207543.2015.1066519

Claffey, E., \& Brady, M. (2014). A model of consumer engagement in a virtual customer environment. Journal of Customer Behaviour, 13(4), 325-346. https://doi.org/10.1362/147539214X14185702584405

Conlon, D. E., \& Murray, N. M. (1996). Customer perceptions of corporate responses to product complaints: The role of explanations. Academy of Management Journal, 39(4), 1040-1056.

Cook, K. S., \& Hegtvedt, K. A. (1983). Distributive justice, equity, and equality. Annual Review of Sociology, 9(1), 217-241. https://doi.org/10.1146/annurev.so.09.080183. $\underline{001245}$

Crisafulli, B., \& Singh, J. (2016). Service guarantee as a recovery strategy: The impact of guarantee terms on perceived justice and firm motives. Journal of Service Management, 27(2), 117-143. https://doi.org/10.1108/JOSM-10-2015-0309

Crisafulli, B., \& Singh, J. (2017). Service failures in e-retailing: Examining the effects of response time, compensation, and service criticality. Computers in Human Behavior, 77, 413-424. https://doi.org/10.1016/j.chb.2017.07.013

Daly, K. (2005). Restorative justice and sexual assault: An archival study of court and conference cases. British Journal of Criminology, 46(2), 334-356. https://doi.org/10.1093/bjc/azi071

Dens, N., De Pelsmacker, P., \& Purnawirawan, N. (2015). "We (b) care" How review set balance moderates the appropriate response strategy to negative online reviews. Journal of Service Management, 26(3), 486-515. https://doi.org/10.1108/JOSM-03$\underline{2014-0082}$

Field, A. (2009). Discovering statistics using SPSS (3rd ed.). London: Sage Publications Inc.

Filip, A., \& Anghel, L. D. (2009). Customer loyalty and its determinants in a banking services environment. Amfiteatru Economic Journal, 11(26), 288-297.

Furby L. (1986). Psychology and justice. In: R. L Cohen (Eds). Justice: Views from the social sciences (pp. 3-30). New York, NY: Plenum. https://doi.org/10.1007/978-1-48993511-3_6

Gelbrich, K., \& Roschk, H. (2011). A meta-analysis of organizational complaint handling and customer responses. Journal of Service Research, 14(1), 24-43. https://doi.org/10.1177 /1094670510387914

Gollan, D. (2015, February 02). Luxury lifts Orlando to record 62 million visitors. Forbes. Retrieved from http://www.forbes.com/sites/douggollan/2015/04/10/orlando-tops-invisitors-with-62-million-mayoral-bliss/\#4590ffe725a7, Accessed date: 30 March 2019.

Gonçalves, H. M., Silva, G. M., \& Martins, T. G. (2018). Motivations for posting online reviews in the hotel industry. Psychology \& Marketing, 35(11), 807-817. https://doi.org/10.1002/mar.21136 
Greenberg, J. (1987). A taxonomy of organizational justice theories. Academy of Management Review, 12(1), 9-22. https://doi.org/10.5465/amr.1987.4306437

Ha, J., \& Jang, S. S. (2009). Perceived justice in service recovery and behavioral intentions: The role of relationship quality. International Journal of Hospitality Management, 28(3), 319-327. https://doi.org/10.1016/j.ijhm.2008.12.001

Hair J. F., Jr., Anderson, R. E., Tatham, R. L., \& Black, W.C. (1998) Multivariate data analysis. Upper Saddle Rivers, NJ: Prentice Hall.

Hennig-Thurau, T., Gwinner, K. P., Walsh, G., \& Gremler, D. D. (2004). Electronic word-ofmouth via consumer-opinion platforms: What motivates consumers to articulate themselves on the Internet?. Journal of Interactive Marketing, 18(1), 38-52. https://doi.org/10.1002/dir.10073

Hess Jr., R. L., Ganesan, S., \& Klein, N. M. (2003). Service failure and recovery: The impact of relationship factors on customer satisfaction. Journal of the Academy of Marketing Science, 31(2), 127-145. https://doi.org/10.1177/0092070302250898

Hocutt, M. A., \& Bowers, M. R. (2005). The impact of service guarantees on consumer responses in the hotel industry. Journal of Hospitality \& Leisure Marketing, 13(1), 523. https://doi.org/10.1300/J150v13n01_02

Hoffman, K. D., Kelley, S. W., \& Rotalsky, H. M. (1995). Tracking service failures and employee recovery efforts. Journal of Services Marketing, 9(2), 49-61. https://doi.org/10.1108/08876049510086017

Hogreve, J., Bilstein, N., \& Mandl, L. (2017). Unveiling the recovery time zone of tolerance: When time matters in service recovery. Journal of the Academy of Marketing Science, 45(6), 866-883. https://doi.org/10.1007/s11747-017-0544-7

Homburg, C., \& Fürst, A. (2005). How organizational complaint handling drives customer loyalty: An analysis of the mechanistic and the organic approach. Journal of Marketing, 69(3), 95-114. https://doi.org/10.1509/jmkg.69.3.95.66367

Huang, W., Mitchell, J., Dibner, C., Ruttenberg, A., \& Tripp, A. (2018, January 16). How customer service can turn angry customers into loyal ones. Harvard Business Review. Retrieved from https://hbr.org/2018/01/how-customer-service-can-turnangry-customers-into-loyal-ones, Accessed date: 30 March 2018.

Jeong, M., \& Lee, S. A. (2017). Do customers care about types of hotel service recovery efforts? An example of consumer-generated review sites. Journal of Hospitality and Tourism Technology, 8(1), 5-18. https://doi.org/10.1108/JHTT-09-2016-0049

Kahneman, D., \& Tversky, A. (1979). Prospect theory: An analysis of decision making under risk. Econometrica, 47(2), 263-292. https://doi.org/10.2307/1914185

Karande, K., Magnini, V. P., \& Tam, L. (2007). Recovery voice and satisfaction after service failure: An experimental investigation of mediating and moderating factors. Journal of Service Research, 10(2), 187-203. https://doi.org/10.1177/1094670507309607

Kelley, S. W., \& Davis, M. A. (1994). Antecedents to customer expectations for service recovery. Journal of the Academy of Marketing Science, 22(1), 52-61. https://doi.org/10.1177/0092070394221005

Kendrick, A. (1998). Promotional products vs price promotion in fostering customer loyalty: A report of two controlled field experiments. Journal of Services Marketing, 12(4), 312-326. https://doi.org/10.1108/08876049810226982

Khoo-Lattimore, C., \& Gibson, H. J. (2018). Understanding women's accommodation experiences on girlfriend getaways: A pragmatic action research approach. Current Issues in Tourism, 21(2), 191-209. https://doi.org/10.1080/13683500.2015.1068745

Kim, T. T., Kim, W. G., \& Kim, H. B. (2009). The effects of perceived justice on recovery satisfaction, trust, word-of-mouth, and revisit intention in upscale hotels. Tourism Management, 30(1), 51-62. https://doi.org/10.1016/j.tourman.2008.04.003 
Kim, W. G., Lim, H., \& Brymer, R. A. (2015). The effectiveness of managing social media on hotel performance. International Journal of Hospitality Management, 44, 165-171. https://doi.org/10.1016/j.ijhm.2014.10.014

Kraska, P. B. (2006). Criminal justice theory: Toward legitimacy and an infrastructure. Justice Quarterly, 23(02), 167-185. https://doi.org/10.1080/07418820600688735

Kuo, Y. F., \& Wu, C. M. (2012). Satisfaction and post-purchase intentions with service recovery of online shopping websites: Perspectives on perceived justice and emotions. International Journal of Information Management, 32(2), 127-138. https://doi.org/10.1016/j.ijinfomgt.2011.09.001

Larsen, G., \& Lawson, R. (2013). Consumer rights: An assessment of justice. Journal of Business Ethics, 112(3), 515-528. https://doi.org/10.1007/s10551-012-1275-9

Latimer, J., Dowden, C., \& Muise, D. (2005). The effectiveness of restorative justice practices: A meta-analysis. The Prison Journal, 85(2), 127-144. https://doi.org/10.1177/0032 $\underline{885505276969}$

Lee, M. C. (2010). Explaining and predicting users' continuance intention toward e-learning: An extension of the expectation-confirmation model. Computers \& Education, 54(2), 506-516. https://doi.org/10.1016/j.compedu.2009.09.002

Lee, Y. G., Yim, B. H., Jones, C. W., \& Kim, B. G. (2016). The extended marketing mix in the context of dance as a performing art. Social Behavior and Personality: An International Journal, 44(6), 1043-1056. https://doi.org/10.2224/sbp.2016.44.6.1043

Lewis, B. R., \& McCann, P. (2004). Service failure and recovery: Evidence from the hotel industry. International Journal of Contemporary Hospitality Management, 16(1), 6-17. https://doi.org/10.1108/09596110410516516

Liao, H. (2007). Do it right this time: The role of employee service recovery performance in customer-perceived justice and customer loyalty after service failures. Journal of Applied Psychology, 92(2), 475-489. https://doi.org/10.1037/0021-9010.92.2.475

Lin, H. C., \& Kalwani, M. U. (2018). Culturally contingent electronic word-of-mouth signaling and screening: A comparative study of product reviews in the United States and Japan. Journal of International Marketing, 26(2), 80-102. https://doi.org/10.1509/jim.17.0016

Lutz, R. J. (1991), The role of attitude theory in marketing. In H. H. Kassarjian \& and T. S. Robertson (Eds.), Perspectives in Consumer Behavior, Englewood Cliffs, NJ: Prentice Hall.

Magnini, V. P., Ford, J. B., Markowski, E. P., \& Honeycutt Jr., E. D. (2007). The service recovery paradox: Justifiable theory or smoldering myth? Journal of Services Marketing, 21(3), 213-225. https://doi.org/10.1108/08876040710746561

Mattila, A. S., \& Cranage, D. (2005). The impact of choice on fairness in the context of service recovery. Journal of Services Marketing, 19(5), 271-279. https://doi.org/10.1108 108876040510609899

Mattila, A. S., \& Patterson, P. G. (2004). Service recovery and fairness perceptions in collectivist and individualist contexts. Journal of Service Research, 6(4), 336-346. https://doi.org/10.1177/1094670503262947

Mattila, A. S., Andreau, L., Hanks, L., \& Kim, E. E. (2013). The impact of cyberostracism on online complaint handling: Is "automatic reply" any better than "no reply"?. International Journal of Retail \& Distribution Management, 41(1), 45-60. https://doi.org/10.1108/09590551311288166

Maxham III, J. G., \& Netemeyer, R. G. (2002). A longitudinal study of complaining customers' evaluations of multiple service failures and recovery efforts. Journal of Marketing, 66(4), 57-71. https://doi.org/10.1509/jmkg.66.4.57.18512 
McCold, P. (1996). Restorative justice and the role of community. In B. Galaway \& J. Hudson (Eds.), Restorative Justice: International Perspectives, (pp. 85-102). Monsey, NY: Criminal Justice Press85, 86.

McColl-Kennedy, J. R., \& Sparks, B. A. (2003). Application of fairness theory to service failures and service recovery. Journal of Service Research, 5(3), 251-266. https://doi.org/10.1177/1094670502238918

McQuilken, L., \& Robertson, N. (2011). The influence of guarantees, active requests to voice and failure severity on customer complaint behavior. International Journal of Hospitality Management, 30(4), 953-962. https://doi.org/10.1016/j.ijhm.2011.02.003

Morrison, B., \& Ahmed, E. (2006). Restorative justice and civil society: Emerging practice, theory, and evidence. Journal of Social Issues, 62(2), 209-215. https://doi.org/10.1111/j.1540-4560.2006.00447.x

Mostafa, R. B., Lages, C. R., Shabbir, H. A., \& Thwaites, D. (2015). Corporate image: A service recovery perspective. Journal of Service Research, 18(4), 468-483. https://doi.org/10.1177/1094670515584146

Mueller, R. D., Palmer, A., Mack, R., \& McMullan, R. (2003). Service in the restaurant industry: an American and Irish comparison of service failures and recovery strategies. International Journal of Hospitality Management, 22(4), 395-418. https://doi.org/10.1016/S02784319(03)00072-0

O'Connor, P. (2010). Managing a hotel's image on TripAdvisor. Journal of Hospitality Marketing \& Management, 19(7), 754-772. https://doi.org/10.1080/19368623.2010. 508007

Oliver, R. L. (1981). Measurement and evaluation of satisfaction processes in retail settings. Journal of Retailing, 57(3), 25-48.

Oliver, R. L. (1987). An investigation of the interrelationship between consumer (dis) satisfaction and complaint reports. In M. Wallendorf \& P. Anderson (Eds.), Advances in Consumer Research (Vol. 14, pp. 218-222). Provo, UT: Association for Consumer Research ACR North American Advances.

Pentina, I., Basmanova, O., Zhang, L., \& Ukis, Y. (2015). Exploring the role of culture in eWOM adoption. MIS Review: An International Journal, 20(2), 1-26. https://doi.org/10.6131/MISR.2015.2002.01

PowerReviews (2018, September 10). The ever-growing power of reviews. Retrieved from https://www.powerreviews.com/blog/the-ever-growing-power-of-reviews/, Accessed date: 30 March 2018.

Proserpio, D., \& Zervas, G. (2017). Online reputation management: Estimating the impact of management responses on consumer reviews. Marketing Science, 36(5), 645-665. https://doi.org/10.1287/mksc.2017.1043

Retzinger, S., \& Scheff, T. J. (1996). Strategy for community conferences: Emotions and social bonds. In B. Galaway \& J. Hudson (Eds.), Restorative Justice: International Perspectives, (pp. 315-336). Monsey, NY: Criminal Justice Press.

Ro, H., \& Wong, J. (2012). Customer opportunistic complaints management: A critical incident approach. International Journal of Hospitality Management, 31(2), 419-427. https://doi.org/10.1016/j.ijhm.2011.06.017

Rodgers, S. (2003). The effects of sponsor relevance on consumer reactions to internet sponsorships. Journal of Advertising, 32(4), 67-76. https://doi.org/10.1080/00913367 .2003 .10639141

Roschk, H., \& Kaiser, S. (2013). The nature of an apology: An experimental study on how to apologize after a service failure. Marketing Letters, 24(3), 293-309. https://doi.org/10. $\underline{1007 / \mathrm{s} 11002-012-9218-\mathrm{X}}$ 
Schlosberg, D. (2013). Theorising environmental justice: The expanding sphere of a discourse. Environmental Politics, 22(1), 37-55. https://doi.org/10.1080/09644016.2013.755387

Schlosser, A. E. (2003). Experiencing products in the virtual world: The role of goal and imagery in influencing attitudes versus purchase intentions. Journal of Consumer Research, 30(2), 184-198. https://doi.org/10.1086/376807

Shanka, T., \& Taylor, R. (2004). An investigation into the perceived importance of service and facility attributes to hotel satisfaction. Journal of Quality Assurance in Hospitality \& Tourism, 4(3-4), 119-134. https://doi.org/10.1300/J162v04n03_08

Sharp, S. (2007). The Ideas of Reparation. In: G. Johnstone \& D. W. Van Ness (Eds.), Handbook of Restorative Justice (pp. 96-108). Hoboken, NJ: Taylor \& and Francis.

Simons Jr, J. V., \& Kraus, M. E. (2005). An analytical approach for allocating service recovery efforts to reduce internal failures. Journal of Service Research, 7(3), 277-289. https://doi.org/10.1177/1094670504271153

Singh, J., \& Crisafulli, B. (2016). Managing online service recovery: procedures, justice and customer satisfaction. Journal of Service Theory and Practice, 26(6), 764-787. https://doi.org/10.1108/JSTP-01-2015-0013

Smith, A. K., Bolton, R. N., \& Wagner, J. (1999). A model of customer satisfaction with service encounters involving failure and recovery. Journal of Marketing Research, 36, 356-372. https://doi.org/10.1177/002224379903600305

Song, J. H., \& Zinkhan, G. M. (2008). Determinants of perceived web site interactivity. Journal of Marketing, 72(2), 99-113. https://doi.org/10.1509/jmkg.72.2.99

Sparks, B. A., \& Bradley, G. L. (2017). A "Triple A" typology of responding to negative consumer-generated online reviews. Journal of Hospitality \& Tourism Research, 41(6), 719-745. https://doi.org/10.1177/1096348014538052

Sparks, B. A., Perkins, H. E., \& Buckley, R. (2013). Online travel reviews as persuasive communication: The effects of content type, source, and certification logos on consumer behavior. Tourism Management, 39, 1-9. https://doi.org/10.1016/j.tour man.2013.03.007

Sparks, B. A., So, K. K. F., \& Bradley, G. L. (2016). Responding to negative online reviews: The effects of hotel responses on customer inferences of trust and concern. Tourism Management, 53, 74-85. https://doi.org/10.1016/j.tourman.2015.09.011

Taber, K. H., Black, D. N., Porrino, L. J., \& Hurley, R. A. (2012). Neuroanatomy of dopamine: reward and addiction. Journal of Neuropsychiatry and Clinical Neurosciences, 24(1), 1-4. https://doi.org/10.1176/appi.neuropsych.24.1.1

Thaler, R. (1985). Mental accounting and consumer choice. Marketing Science, 4(3), 199-214. https://doi.org/10.1287/mksc.4.3.199

Thibaut, J. W., \& Walker, L. (1975). Procedural justice: A psychological analysis. Hillsdale, NJ: Erlbaum.

Tversky, A., \& Kahneman, D. (1992). Advances in prospect theory: Cumulative representation of uncertainty. Journal of Risk and Uncertainty, 5(4), 297-323. https://doi.org/10.1007/BF00122574

Umbreit, M. S., Coates, R. B., \& Kalanj, B. (1994). Victim meets offender: The impact of restorative justice and mediation (pp. 53-64). Monsey, NY: Criminal Justice Press.

Umbreit, M. S., Coates, R. B., \& Roberts, A. W. (2000). The impact of victim-offender mediation: A cross-national perspective. Mediation Quarterly, 17(3), 215-229. https://doi.org/10.1002/crq.3900170303

Umbreit, M. S., Coates, R. B., \& Vos, B. (2004). Victim-offender mediation: Three decades of practice and research. Conflict Resolution Quarterly, 22(1/-2), 279-303. https://doi.org/10.1002/crq.102 
Vaandering, D. (2013). A window on relationships: Reflecting critically on a current restorative justice theory. Restorative Justice, 1(3), 311-333. https://doi.org/10.5235/20504721.1 .3 .311

Van Vaerenbergh, Y., Varga, D., De Keyser, A., \& Orsingher, C. (2018 in press). The service recovery journey: Conceptualization, integration, and directions for future research. Journal of Service Research. https://doi.org/10.1177/1094670518819852

Wallin Andreassen, T. (2000). Antecedents to satisfaction with service recovery. European Journal of Marketing, 34(1/2), 156-175. https://doi.org/10.1108/03090560010306269

Wang, Y. S., Wu, S. C., Lin, H. H., \& Wang, Y. Y. (2011). The relationship of service failure severity, service recovery justice and perceived switching costs with customer loyalty in the context of e-tailing. International Journal of Information Management, 31(4), 350-359. https://doi.org/10.1016/j.ijinfomgt.2010.09.001

Wemmers, J. A. (2002). Restorative justice for victims of crime: A victim-oriented approach to restorative justice. International Review of Victimology, 9(1), 43-59. https://doi.org/10.1177/026975800200900104

Weun, S., Beatty, S. E., \& Jones, M. A. (2004). The impact of service failure severity on service recovery evaluations andpost-recovery relationships. Journal of Services Marketing, 18(2), 133-146. https://doi.org/10.1108/08876040410528737

Wirtz, J., \& Mattila, A. S. (2004). Consumer responses to compensation, speed of recovery and apology after a service failure. International Journal of Service Industry Management, 15(2), 150-166. https://doi.org/10.1108/09564230410532484

Wu, L., Mattila, A. S., Wang, C. Y., \& Hanks, L. (2016). The impact of power on service customers' willingness to post online reviews. Journal of Service Research, 19(2), 224238. https://doi.org/10.1177/1094670516630623

Wu, L., Shen, H., Fan, A., \& Mattila, A. S. (2017). The impact of language style on consumers' reactions to online reviews. Tourism Management, 59, 590-596. https://doi.org /10.1016/j.tourman.2016.09.006

Xie, K. L., Zhang, Z., \& Zhang, Z. (2014). The business value of online consumer reviews and management response to hotel performance. International Journal of Hospitality Management, 43, 1-12. https://doi.org/10.1016/j.ijhm.2014.07.007

Yani-de-Soriano, M., Hanel, P. H., Vazquez-Carrasco, R., Cambra-Fierro, J., Wilson, A., \& Centeno, E. (2019 in press). Investigating the role of customers' perceptions of employee effort and justice in service recovery: A cross-cultural perspective. European Journal of Marketing. https://doi.org/10.1108/EJM-09-2017-0570

Ye, Q., Gu, B., Chen, W., \& Law, R. (2008). Measuring the value of managerial responses to online reviews: -A natural experiment of two online travel agencies. ICIS 2008 Proceedings, (pp. 115-122). Atlanta: Association for Information Systems.

Yeh, Y. H., \& Choi, S. M. (2011). MINI-lovers, maxi-mouths: An investigation of antecedents to eWOM intention among brand community members. Journal of Marketing Communications, 17(3), 145-162. https://doi.org/10.1080/13527260903351119

Yeoh, P. L., Woolford, S. W., Eshghi, A., \& Butaney, G. (2014). Customer response to service recovery in online shopping. Journal of Services Research, 14(2), 33-56.

Zhang, T., Abound Omran, B., \& Cobanoglu, C. (2017). Generation Y's positive and negative eWOM: use of social media and mobile technology. International Journal of Contemporary Hospitality Management, 29(2), 732-761. https://doi.org/10.1108/IJC HM-10-2015-0611

Zhao, L., \& Lu, Y. (2012). Enhancing perceived interactivity through network externalities: An empirical study on micro-blogging service satisfaction and continuance intention. Decision Support Systems, 53(4), 825-834. https://doi.org/10.1016/j.dss.2012.05.019 
Zheng, Y., Zhao, K., \& Stylianou, A. (2013). The impacts of information quality and system quality on users' continuance intention in information-exchange virtual communities: An empirical investigation. Decision Support Systems, 56, 513-524. https://doi.org/10.1016/j.dss.2012.11.008

Zhu, L., Yin, G., \& He, W. (2014). Is this opinion leader's review useful? Peripheral cues for online review helpfulness. Journal of Electronic Commerce Research, 15(4), 267-280.

Zhu, Z., Sivakumar, K., \& Parasuraman, A. (2004). A mathematical model of service failure and recovery strategies. Decision Sciences, 35(3), 493-525. https://doi.org/10.1111 /j.00117315.2004.02597.x 